\title{
CAMPUR KODE PENGGUNAAN BAHASA INDONESIA OLEH MAHASISWA THAILAND DI UNIVERSITAS JEMBER
}

\section{A STUDY ON THE USE OF INDONESIAN LANGUANGE CODE MIXING BY THAILAND FOREIGN STUDENT AT JEMBER UNIVERSITY}

\author{
Nurul Azizah ${ }^{1}$, A. Erna Rochiyati S. ${ }^{2 *}$, Edy Hariyadi ${ }^{3}$ \\ ${ }^{1}$ Alumni Fakultas Ilmu Budaya, Universitas Jember \\ ${ }^{2,3}$ Fakultas Ilmu Budaya, Universitas Jember \\ *Corresponding Author: erna.rochiyati@gmail.com \\ Informasi Artikel: \\ Dikirim: 2/12/2018; Direvisi: 25/01/2019; Diterima: 30/02/2019
}

\begin{abstract}
Code mixing is a state of language use by speakers by mixing two (or more) languages in one speech without any cause for the mixture of languages. One of these codes mixes in the communication process of Thai University students at Jember when using Indonesian. Code interfering events occur when used as communication tools and adaptation tools, interact daily and in the learning process. This study uses a qualitative descriptive method using a sociolinguistic approach. The data in this study are Thai student speeches when using Indonesian. The results showed that mixed code was found when Thai students used Indonesian. From the results of the study found three mixed codes: 1) mixed word code, 2) mixed code form phrases, and mixed code form clauses. The code interfering factors include: 1) regional sense factors, 2) financial factors to explain and interpret, 3) factors in the absence of concepts or terms in Indonesian, and 4) factors of limitations in mastering Indonesian.
\end{abstract}

Keywords: mixed code, sociolinguistics, Thai students

Abstrak

Campur kode adalah suatu keadaan pemakaian bahasa oleh penutur dengan mencampur dua (atau lebih) bahasa dalam satu tuturan tanpa ada penyebab terjadinya percampuran bahasa itu. Campur kode tersebut salah satunya terjadi dalam proses komunikasi mahasiswa Thailand di Universitas Jember saat menggunakan bahasa Indonesia. Peristiwa campur kode terjadi ketika digunakan sebagai alat komunikasi dan alat adaptasi, dalam berinteraksi sehari-hari serta pada proses belajar. Penelitian ini menggunakan metode deskriptif kualitatif dengan menggunakan pendekatan sosiolinguistik. Data dalam penelitian ini berupa tuturan mahasiswa Thailand saat menggunakan bahasa Indonesia. Hasil penelitian menunjukkan bahwa campur kode yang ditemukan saat mahasiswa Thailand menggunakan bahasa Indonesia ditemukan tiga bentuk campur kode: 1) campur kode bentuk kata, 2) campur kode bentuk frasa, dan 3) campur kode bentuk klausa. Faktor penyebab campur kode meliputi: 1) faktor rasa kedaerahan, 2) faktor keingginan untuk menjelaskan dan menafsirkan, 3) faktor tidak adanya konsep atau istilah dalam bahasa Indonesia, dan 4) faktor keterbatasan dalam penguasaan bahasa Indonesia.

Kata kunci: campur kode, sosiolinguistik, mahasiswa Thailand 


\section{PENDAHULUAN}

Manusia hakikatnya hidup bersosial, berinteraksi antara manusia satu dengan manusia yang lain. Salah satu cara untuk berinteraksi yaitu dengan komunikasi. Bahasa digunakan untuk penyampaian maksud dari penuturnya dalam berkomunikasi. Beberapa fungsi bahasa adalah untuk menyatakan hasil pemikiran, alat pergaulan, dan menghubungan dengan sesama manusia, sehingga terbentuk sistem sosial masyarakat. Dalam fungsinya tersebut, bahasa memiliki seperangkat aturan yang disepakati para penuturnya. Dari beragam fungsi bahasa, beberapa pakar bersepakat bahwa fungsi utama bahasa adalah sebagai alat komunikasi dan berinteraksi.

Terkait penjabaran tentang bahasa, dapat diambil garis besar bahwa semua manusia di dunia ini sama-sama berbudaya dengan fasilitas bahasa. Berdasarkan bahasa yang digunakan maka ditemukan juga cara tuturan atau ujaran. Suwito (1983:3) mengatakan bahwa bahasa pada dasarnya tidak hanya merupakan gejala individu, tetapi juga merupakan gejala sosial sehingga terdapat ragam penggunaan dan fungsi-fungsinya sesuai dengan lawan tutur, situasi tuturan, dan topik tuturan. Dalam hal ini, sering terjadinya proses komunikasi campur kode.

Thelander (dalam Suwito 1983:76) mendefisikan campur kode sebagai peristiwa tutur yang terdapat frase-frase campuran dari frase bahasa lain yang masing-masing frase tidak mendukung fungsi sendiri-sendiri. Campur kode adalah salah satu kajian dalam sosiolinguistik. Sosiolinguistik adalah ilmu interdisipliner yang menggeluti dan menyusun teori-teori tentang hubungan masyarakat dan bahasa (Alwasilah, 1993:1). Sebagai masyarakat tutur, mahasiswa asing -khususnya mahasiswa Thailand- memiliki karakteristik kebahasaan yang menarik untuk dikaji. Mahasiswa Thailand yang menempuh pendidikan di Universitas Jember terbagi atas beberapa wilayah di Thailand Selatan di antaranya, yaitu wilayah Narathiwat, Yala, Songkhla, dan Pattani. Mereka menggunakan dua bahasa yaitu bahasa Thailand dan bahasa Melayu Pattani. Oleh karena itu, mahasiswa Thailand di Universitas Jember sebagai dwibahasawan dan dalam berinteraksi sehari-hari terjadi campur kode.

Dalam berinteraksi mereka melakukan campur kode secara tidak sengaja. Contoh seorang mahasiswa Thailand menggunakan kata "bisa" mempunyai makna racun dalam bahasa Melayu Pattani (Duerawee, 2016) sedangkan dalam bahasa Indonesia (KBBI V 0.2.1 Beta (21), 2016) mempunyai makna yang luas yaitu bermakna mampu, sesuatu yang dapat menyebabkan luka, racun, dan sapaan kepada dukun yang berasal dari golongan bangsawan. Dari contoh kata itu, apat dikatakan bahwa antara bahasa Indonesia dan bahasa Melayu Pattani tidak berbeda jauh hanya bahasa Indonesia memiliki makna yang lebih luas. Mahasiswa Thailand saat berkomunikasi dengan mahasiswa Indonesia terjadi beberapa campur kode bahasa yaitu bahasa Indonesia, bahasa Thailand, dan bahasa Melayu Pattani.

Penelitian pertama tentang campur kode, dilakukan oleh Afrisal Mariagi (2011) berjudul "Campur Kode Bahasa Inggris terhadap Bahasa Indonesia di Tabliod Bola: Tinjauan Sosiolinguistik". Meskipun judulnya hanya mencakup campur kode bahasa Inggris, tetapi dalam pembahasannya terdapat pula campur kode bahasa Italia. Penelitian ini mengambil objek kajian campur kode bahasa Inggris dan Italia terhadap bahasa Indonesia di Tabloid BOLA. Penelitian kedua, dilakukan oleh Serly Ari Yuanita (2012) berjudul "Campur Kode Bahasa Jawa terhadap Bahasa Indonesia dalam Interaksi Pembelajaran Guru di SMPN 1 Muncar, Kecamatan Muncar, Kabupaten Banyuwangi”. Skripsi tersebut mendeskripsikan wujud campur kode bahasa Jawa terhadap bahasa Indonesia dalam bentuk kata dasar, kata 
berimbuan, kata ulang, kata majemuk, frasa, dan klausa. Penelitian ketiga, dilakukan oleh Ahmad Ainur Rosyid (2015) berjudul "Campur Kode dalam Interaksi Santri Penutur Bahasa Madura di Lingkungan Sekolah MTS Unggulan Nurul Islam Antirogo Jember”. Penelitian ini mengambil bentuk-bentuk campur kode bahasa Madura oleh seorang santri dan faktor-faktor yang melatarbelakangi terbentuknya campur kode bahasa Madura dalam ranah sekolah MTS Unggulan Nurul Islam Antirogo Jember. Hasil penelitian ini yaitu berupa campur kode dalam beberapa interaksi yaitu interaksi sesama santri, interaksi santri dengan ustaz atau ustazah, dan interaksi santri dengan kyai.

Dari penelitian yang disebutkan di atas, penelitian ini memiliki persamaan dan perbedaan. Penelitian ini berjudul "Campur Kode pada Penggunaan Bahasa Indonesia oleh Mahasiswa Thailand Universitas Jember". Persamaan dengan penelitian sebelumnya yaitu sama-sama mendeskripsikan bentuk dan faktor-faktor yang mempengaruhi terjadinya campur kode serta menggunakan kajian ilmu sosiolinguistik untuk menyelesaian masalah-masalah yang ada dalam penelitian. Perbedaannya yaitu pada objek penelitian.

Rumusan masalah dalam penelitian ini sebagai berikut. (1) Bagaimanakah bentukbentuk campur kode mahasiswa Thailand di Universitas Jember dalam penggunaan bahasa Indonesia? (2) Apakah faktor yang melatarbelakangi terjadinya campur kode pada mahasiswa Thailand di Universitas Jember dalam penggunaan bahasa Indonesia?

\section{METODE}

Penelitian ini berjenis penelitian deskriptif dengan pendekatan kualitatif. Penyediaan data dalam penelitian ini menggunakan prosedur secara sistematis. 1) Metode penyediaan data menggunakan metode simak dan metode wawancara. Metode simak dengan teknik dasar yaitu teknik sadap, dilanjutkan dengan teknik lanjutan SBLC (Simak Bebas Libat Cakap), teknik rekam, dan teknik catat. Metode wawancara dilaksanakan wawancara bebas terpimpin. 2) Metode analisis data yaitu metode agih dan metode padan. Metode agih pada penelitian ini menggunakan teknik dasar BUL untuk mengetahui bentuk campur kode. Metode agih menggunakan teknik dasar yaitu teknik pilah unsur penentu (PUP) dilanjutkan dengan teknik lanjutan yaitu teknik hubung banding mempersamakan (HBS) dan teknik hubung membedakan (HBB). 3) Metode penyajian hasil analisis data dengan metode penyajian informal.

\section{HASIL DAN PEMBAHASAN}

Campur kode mahasiswa Thailand Universitas Jember dalam menggunakan bahasa Indonesia adalah campur kode yang melibatkan unsur-unsur bahasa lain (bahasa Thailand dan bahasa Melayu Pattani) ke dalam penggunaan bahasa Indonesia oleh mahasiswa Thailand Universitas Jember. Bentuk campur kode yang dianalisis dalam penelitian ini ditinjau dari hasil interaksi mahasiswa Thailand dengan mahasiswa Indonesia. Hasil penelitian campur kode ini terdiri atas dua bagian, yang pertama bentuk-bentuk campur kode dan yang kedua faktor-faktor yang menyebabkan terjadinya campur kode. Bagian-bagian tersebut akan dibahas berikut ini. 


\section{Bentuk-bentuk Campur Kode Mahasiswa Thailand di Universitas Jember dalam Penggunaan Bahasa Indonesia}

Beragam bentuk campur kode dalam interaksi mahasiswa Thailand Universitas Jember dalam menggunakan bahasa Indonesia, terdiri atas: campur kode bentuk kata, bentuk frasa, dan bentuk klausa. Bentuk-bentuk campur kode tersebut dijabarkan berikut ini.

\section{Campur Kode Bentuk Kata}

Campur kode berbentuk kata yang terjadi saat mahasiswa Thailand Universitas Jember berinteraksi meliputi: campur kode bentuk kata dasar, bentuk kata imbuhan, dan bentuk kata ulang.

Campur kode mahasiswa Thailand Universitas Jember bentuk kata dasar. Kata dasar adalah kata yang menjadi dasar awal bentukan bagi satuan yang lebih besar. Selain itu, kata dasar merupakan kata yang belum diberi imbuhan. Data campur kode mahasiswa Thailand Universitas Jember dalam penggunaan bahasa Indonesia dapat diperhatikan pada beberapa data berikut ini.

Konteks situasi :

Peristiwa tutur dilakukan oleh dua orang, orang pertama (O1) bernama Ayu dan orang kedua $(\mathrm{O} 2)$ bernama Afnan. Dalam peristiwa tersebut Afnan (O2) mahasiswa Thailand dan Ayu mahasiswa Indonesia. Mereka merupakan mahasiswa Jurusan Sastra Indonesia dan satu angkatan yaitu Angkatan 2016. Percakapan terjadi di depan ruang kelas Fakultas Ilmu Budaya pada waktu istirahat di antara jam kuliah. Mereka sedang membicarakan rasa khas makanan di Thailand. Percakapan dimulai saat (O1) menawarkan makanan kepada (O2). Pada saat itu (O2) menanggapi pertanyaan dengan menggunakan bahasa Indonesia yang pada beberapa kata mengalami percampuran istilah bahasa lain yaitu bahasa Melayu Pattani. Kemudian (O1) menanggapi dengan sebuah pertanyaan untuk memastikan istilah bahasa tersebut, sesuai dengan arti yang dimengerti oleh (O1). (O2) menanggapi pertanyaan dari (O1) yang berisi pembenaran dari apa yang dimaksud (O1) hampir mirip dengan (O2) maksud. Hal itu seperti yang terdapat pada data di bawah ini.

Mahasiswa 1.1: Kamu tau tape? Tape yang dari Bondowoso itu lo.

Mahasiswa 2.1: Iya tau.

Mahasiswa 1.2: Mau ini dong? Ambil dah makan.

Mahasiswa 2.2: Iya terima kasih.

Mahasiswa 1.3: Kalau di sini suku Jawa makanannya cenderung manis, kalau di Thailand?

Mahasiswa 2.3: Di sana itu masae [mase] gitu.

'Di sana itu rasa asam'

Mahasiswa 1.4: Masae itu kayak kecut gitu?

Mahasiswa 2.4: Iya kecut tapi ada manisnya.

Campur kode dari data di atas terjadi saat (O1) dan (O2) menggunakan tuturan bahasa Indonesia dan di dalamnya tercampur dengan bahasa Melayu Pattani. Bentuk campur kode terjadi saat tuturan $2.3(\mathrm{O} 2)$ berupa kata masae [masc], yang dalam bahasa Indonesia artinya 
Campur Kode Penggunaan Bahasa Indonesia oleh Mahasiswa Thailand di Universitas Jember (Nurul Azizah, A. Erna Rochiyati S., Edy Hariyadi)

'asam' (Awabeen, Pembicaraan pribadi, 6 Maret 2019). Kata asam memiliki makna 'rasa seperti rasa cuka (KBBI V 0.2.1 Beta (21), 2016). Kata asam merupakan kata dasar dan termasuk jenis kata sifat. Kata masae dalam konteks ini mempunyai maksud asam tetapi ada rasa manisnya.

Campur kode mahasiswa Thailand Universitas Jember berbentuk kata imbuhan. Afiksasi adalah proses pembentukan kata dengan membubuhkan afiks atau imbuhan (Ramlan 1983:45). Campur kode bentuk kata berimbuhan maksudnya yaitu masuknya unsur-unsur bahasa Thailand atau bahasa Melayu Pattani yang berupa kata berimbuhan saat mahasiswa Thailand Universitas Jember berinteraksi menggunakan bahasa Indonesia. Data campur kode bentuk kata imbuhan oleh mahasiswa Thailand Universitas Jember dalam penggunaan bahasa Indonesia dapat diperhatikan pada data berikut ini.

Konteks situasi :

Peristiwa tutur dilakukan oleh dua orang, orang pertama (O1) bernama Ririn dan orang kedua (O2) bernama Aseesah. Dalam peristiwa tersebut Aseesah (O2) mahasiswa Thailand Jurusan Pendidikan Bahasa Indonesia FKIP Angkatan 2016 dan Ririn mahasiswa Indonesia Jurusan Pendidikan Luar Sekolah FKIP Angkatan 2015. Peristiwa tutur terjadi di taman kampus FKIP Gedung 3 pada saat istirahat kuliah. Mereka sedang membicarakan metode pembelajaran yang diterapkan di Thailand. Ririn mahasiswa semester 7 yang hendak menyusun skripsi dan ingin mencari contoh metode pembelajaran sebagai bahan skripsinya. Percakapan dimulai saat (O1) menanyakan sistem pendidikan kepada $(\mathrm{O} 2)$. Pada saat itu, $(\mathrm{O} 2)$ menanggapi pertanyaan dengan menggunakan bahasa Indonesia yang pada beberapa kata mengalami percampuran istilah bahasa lain yaitu bahasa Melayu Pattani. Kemudian (O1) menanggapi dengan menggunakan bahasa Indonesia Hal itu seperti yang terdapat pada data di bawah ini.

Mahasiswa 1.1: Sistem pendidikan di Thailand seperti apa?

Mahasiswa 2.1: Kalau sistem pendidikae [pendidike] di Thailand itu cenderung pada guru, kalau di sini kan ada pertanyaan murid sama guru kalau di sana beda.

'Kalau sistem pendidikan di Thailand itu cenderung pada guru, kalau di sini kan ada pertanyaan murid sama guru, kalau di sana beda.'

Mahasiswa 1.2: Kan Jurusan PBSI, itu gimana prakteknya?

Mahasiswa 2.2: Iya itu masih semester 6.

Mahasiswa 1.3: Rencananya mau pakai metode yang di Thailand atau metode di Indonesia?

Mahasiswa 2.3: Kalau hal itu belum tau, tapi ya tergantung tempatnya nanti.

Campur kode dari data di atas terjadi saat $(\mathrm{O} 2)$ menggunakan tuturan bahasa Indonesia yang di dalamnya tercampur dengan tuturan bahasa Melayu Pattani. Campur kode terjadi dalam tuturan 2.1 berupa kata pendidikae [pendidike] yang dalam bahasa Indonesia artinya'pendidikan'. Bahasa Melayu Pattani mengubah kata berakhiran -an dan -am menjadi vokal [e] (www.surabaya.tribunnews.com/2016). Kata pendidikae [pendidike] sama dengan kata pendidikan dalam bahasa Indonesia, terbentuk atas dua morfem, yaitu bentuk asal didik + pe $(\mathrm{N})$-an. Kata pendidikan memiliki makna 'proses pengubahan sikap dan tata laku 
seseorang atau kelompok orang dalam usaha mendewasakan manusia melalui upaya pengajaran dan pelatihan' (KBBI V 0.2.1 Beta (21), 2016). Kata pendidikae merupakan kata berimbuhan kata asalnya kata didik yang mendapatkan imbuhan pe(N)+-ae dan berjenis kata benda.

Campur kode mahasiswa Thailand Universitas Jember berbentuk kata ulang. Kata ulang atau reduplikasi adalah sebuah kata yang mengalami perulangan. Proses pengulangan atau reduplikasi adalah pengulangan satuan gramatik, baik seluruh maupun sebagian, baik dengan variasi fonem maupun tidak (Ramlan, 1983:55). Campur kode bentuk kata ulang maksudnya yaitu masuknya unsur-unsur bahasa Thailand atau bahasa Melayu Pattani yang berupa kata ulang saat mahasiswa Thailand Universitas Jember berinteraksi menggunakan bahasa Indonesia. Data yang berbentuk kata ulang berupa pengulangan seluruhnya. Pengulangan seluruhnya adalah pengulangan seluruh bentuk dasar, tanpa perubahan fonem dan tidak berkombinasi dengan proses pembubuhan afiks (Ramlan, 1983:60). Data campur kode bentuk kata ulang mahasiswa Thailand Universitas Jember dalam penggunaan bahasa Indonesia dapat diperhatikan pada data berikut ini.

Konteks situasi :

Peristiwa tutur dilakukan oleh dua mahasiswa, Mahasiswa pertama (O1) bernama Yuan dan Mahasiswa kedua (O2) bernama Asma. Dalam peristiwa tersebut Asma (O2) mahasiswa Thailand dan Ayu mahasiswa Indonesia. Mereka merupakan mahasiswa Jurusan Sastra Indonesia dan teman seangkatan yaitu Angkatan 2016. Percakapan terjadi di depan ruang kelas Fakultas Ilmu Budaya Universitas Jember saat selesai mengikuti UAS. Mereka sedang mendiskusikan tentang soal yang diujikan di UAS. Percakapan dimulai saat (O1) menanyakan soal yang diujikan saat UAS kepada (O2). Pada saat itu (O2) menanggapi pertanyaan dengan menggunakan bahasa Indonesia yang pada beberapa kata mengalami percampuran istilah bahasa lain, yaitu bahasa Thailand. Kemudian (O1) menanggapi dengan menggunakan bahasa Indonesia Hal itu seperti yang terdapat pada data di bawah ini.

Mahasiswa 1.1: Gimana UASnya kamu? Gimana bisa?

Mahasiswa 2.1: Tak leh, banyak yang belum selesai.

Mahasiswa 1.2: Tadi nomer berapa yang sulit?

Mahasiswa 2.2: Puisi itu.

Mahasiswa 1.3: Sulit semua?

Mahasiswa 2.3: Iya, tapi Cĥ̄ā-Cĥ̄ā [chaa-chaa] tadi aku belum nomer 6.

'Iya tapi pelan-pelan tadi aku belum nomer 6'

Mahasiswa 1.4: Yang puisi kamar mandi?

Mahasiswa 2.4: Iya sama nomer 5 masih kurang.

Mahasiswa 1.5: Yang mana?

Mahasiswa 2.5: Yang masalah angkatan puisi.

Campur kode pada dialog di atas terjadi saat (O2) menggunakan tuturan bahasa Indonesia yang di dalamnya tercampur dengan tuturan bahasa Thailand. Campur kode terjadi dalam tuturan 2.3 berupa kata $\mathbf{c h} \overline{\mathbf{a}}$-cĥ̄à [chaa-chaa] yang dalam bahasa Indonesia artinya 'pelan- 
Campur Kode Penggunaan Bahasa Indonesia oleh Mahasiswa Thailand di Universitas Jember (Nurul Azizah, A. Erna Rochiyati S., Edy Hariyadi)

pelan'(www.kompasiana.com/2011). Kata cĥ̄ā-chāa [chaa-chaa] dalam bahasa Indonesia sama halnya dengan kata pelan-pelan yang terbentuk dari pengulangan secara penuh kata pelan. Kata pelan-pelan memiliki makna 'perlahan-lahan atau tidak keras'(KBBI V 0.2.1 Beta (21), 2016).

\section{Campur Kode yang Berbentuk Frasa}

Campur kode bentuk frasa adalah menyisipkan unsur-unsur bahasa Thailand atau bahasa Melayu Pattani berupa frasa ke dalam konteks kalimat saat mahasiswa Thailand menggunakan bahasa Indonesia. Frasa ialah satuan gramatikal yang berupa gabungan kata yang bersifat nonpredikatif, atau gabungan kata yang mengisi salah satu fungsi sintaksis di dalam kalimat (Chaer, 2012:222). Data yang berbentuk frasa terdiri atas: frasa nominal, frasa verbal, dan frasa ajektival. Campur kode yang berbentuk klausa tersebut dapat dilihat pada bentuk data berikut.

Konteks situasi :

Peristiwa tutur dilakukan oleh dua orang, orang pertama (O1) bernama Risca dan orang kedua $(\mathrm{O} 2)$ bernama Ainee. Dalam peristiwa tersebut Ainee (O2) mahasiswa Thailand dan Risca mahasiswa Indonesia. Mereka merupakan mahasiswa Jurusan Ilmu Ekonomi Studi Pembangunan dan teman seangkatan yaitu Angkatan 2017. Percakapan terjadi di Gazebo Fakultas Ekonomi dan Bisnis Universitas Jember saat istirahat kuliah. Percakapan dimulai saat (O1) menanyakan keberadaan (O2) saat kuliah libur. Pada saat itu (O2) menanggapi pertanyaan dengan menggunakan Bahasa Indonesia yang pada beberapa kata mengalami percampuran istilah bahasa lain yaitu bahasa Melayu Pattani. Kemudian (O1) menanggapi dengan menggunakan bahasa Indonesia. Hal itu seperti yang terdapat pada data di bawah ini.

Mahasiswa 1.1: Kamu katanya pulang pas liburan besok?

Mahasiswa 2.1: Iya aku mau pulang. Minggu depan itu.

Mahasiswa 1.2: Kamu naik apa?

Mahasiswa 2.2: Naik bus boleh kok?

Mahasiswa 1.3: Berapa jam naik bus?

Mahasiswa 2.3: Kalau sini ke Juanda tak sampai lapae jae [lape jeh].

'Kalau dari sini ke Juanda tak sampai delapan jam'

Mahasiswa 1.4: Lama ya.

Mahasiswa 2.4: Iya itu tergantung kamu nak naik apa.

Mahasiswa 1.5: Oh gitu.

Campur kode dari data di atas terjadi saat (O1) dan (O2) menggunakan tuturan bahasa Indonesia dan di dalamnya tercampur dengan bahasa Melayu Pattani. Bentuk campur kode terjadi saat tuturan $2.3(\mathrm{O} 2)$ berupa frasa lapae jae [lape jeh] yang dalam bahasa Indonesia artinya 'delapan jam' (Awabeen, Pembicaraan pribadi, 6 Maret 2019). Frasa lapae jae terdiri atas dua kata yaitu lapae dan jae. Kata lapae 'delapan' merupakan kata dasar dan termasuk jenis kata bilangan, memiliki makna 'urutan sesudah ke-7' dan kata jae 'jam' merupakan kata dasar dan termasuk jenis kata benda, memiliki makna 'waktu' (KBBI V 0.2.1 Beta (21), 
2016). Kata delapan dalam Bahasa Indonesia berubah menjadi lapae dalam bahasa Melayu Pattani sehingga mengalami proses penyingkatan kata de pada awal kata hilang (www.surabaya.tribunnews.com/2015). Frasa lapae jae [lape jeh] memiliki kata asal delapan dan jam yang mengalami perubahan akhir kata karena untuk kata berakhiran -an dan -am dalam bahasa Melayu Pattani akan berubah vokal [e] (www.surabaya.tribunnews.com/2016) dan termasuk dalam frasa numeralia. Frasa numeralia adalah frasa endosentrik yang intinya berupa nominal atau pronomina (Chaer, 2012:228).

\section{Campur Kode yang Berbentuk Klausa}

Campur kode bentuk klausa terjadi bila terjadi penyisipan unsur bahasa Thailand atau bahasa Melayu Pattani berbentuk klausa dalam konteks kalimat bahasa Indonesia. Klausa merupakan satuan gramatik yang terdiri atas subjek dan predikat baik disertai unsur objek, perlengkapan, dan keterangan atau tidak (Ramlan, 1987:89). Adapun campur kode yang berbentuk klausa tersebut dapat dilihat pada bentuk tuturan dan konteks berikut.

Konteks situasi :

Peristiwa tutur dilakukan oleh dua orang, orang pertama (O1) bernama Fatiha mahasiswa Thailand dan orang kedua (O2) bernama Maslahah mahasiswa Indonesia. Dua-duanya merupakan mahasiswa Jurusan Sejarah dan teman seangkatan yaitu Angkatan 2015. Percakapan terjadi di Gazebo Fakultas Ilmu Budaya Universitas Jember. Mereka sedang membicarakan apakah $(\mathrm{O} 2)$ jadi pergi ke sekretariat anak Thailand. Percakapan dimulai saat (O1) memastikan (O2) benar datang ke sekretariat anak Thailand dengan menggunakan bahasa Indonesia. Kemudian percakapan berlanjut hingga saat itu (O1) dalam tuturannya terjadi percampuran istilah bahasa lain yaitu bahasa Melayu Pattani. Pada saat itu (O2) menanggapi dengan menggunakan bahasa Indonesia. Hal itu seperti yang terdapat pada data di bawah ini.

Mahasiswa 1.1: Kamu ke sekret sama siapa kemarin?

Mahasiswa 2.1: Sama Nurul.

Mahasiswa 1.2: Kamu kost di mana?

Mahasiswa 2.2: Di jawa 6 sebelum cak Us.

Mahasiswa 1.3: Maaf ya kemarin sayo gi doh [sayO gIdOh] ke Tulungagung.

'Maaf ya kemarin saya sudah pergi ke Tulungagung'

Campur kode dari data di atas terjadi saat (O1) dan (O2) menggunakan tuturan bahasa Indonesia dan di dalamnya tercampur dengan bahasa Melayu Pattani. Bentuk campur kode terjadi saat tuturan 1.3 (O1) berupa klausa sayo gi doh [sayO gI dOh] yang dalam bahasa Indonesia artinya 'saya sudah pergi' (www.surabaya.tribunnews.com/2016). Klausa sayo gi doh terdiri atas tiga kata yaitu sayo 'saya', doh 'sudah', dan gi 'pergi' tetapi ketiganya mengalami proses penyingkatan (www.surabaya.tribunnews.com/2016). Kata sayo merupakan kata ganti yang mengisi fungsi subjek dan memiliki makna 'aku', kata doh merupakan kata keterangan yang mengisi fungsi keterangan predikat dan memiliki makna 'telah', dan kata gi merupakan kata kerja yang mengisi fungsi predikat dan memiliki makna 'meninggalkan' (KBBI V 0.2.1 Beta (21), 2016). klausa sayo gi doh [sayO gI dOh] 
Campur Kode Penggunaan Bahasa Indonesia oleh Mahasiswa Thailand di Universitas Jember (Nurul Azizah, A. Erna Rochiyati S., Edy Hariyadi)

merupakan klausa bebas. Klausa bebas adalah klausa yang mempunyai unsur-unsur lengkap, sekurang-kurangnya mempunyai subjek dan predikat (Chaer, 2012:235).

\section{Faktor yang Melatarbelakangi Terjadinya Campur Kode pada Mahasiswa Thailand di Universitas Jember dalam Menggunakan Tuturan Bahasa Indonesia}

Campur kode ialah suatu keadaan berbahasa penutur mencampur dua (atau lebih) bahasa atau ragan bahasa dalam satu tindakkan bahasa (speech act atau discourse) tanpa ada sesuatu dalam situasi berbahasa itu yang menuntut percampuran bahasa itu (Nababan, 1986: 32). Campur kode terjadi apabila seorang penutur menggunakan suatu bahasa secara dominan mendukung suatu tuturan disisipi dengan unsur bahasa lainnya. Kenyataannya campur kode tidak mempunyai maksud dan tujuan yang jelas untuk digunakan, karena campur kode biasanya digunakan tidak disadari oleh seorang penutur, sehingga peristiwa campur kode tidak bisa lepas dengan penutur. Penutur berperan dalam memasuukkan unsur-unsur bahasa lain ke dalam pemakaian bahasa Indonesia. Faktor-faktor yang menyebabkan terjadinya peristiwa campur kode mahasiswa Thailand di Universitas Jember saat menggunakan bahasa Indonesia terdiri atas; 1) faktor rasa kedaerahan, 2) faktor keinginan untuk menjelaskan dan menafsirkan, 3) faktor tidak adanya konsep atau istilah dalam bahasa Indonesia, dan 4) faktor keterbatasan dalam penguasaan bahasa Indonesia

\section{Faktor Rasa Kedaerahan}

Campur kode karena faktor rasa kedaerahan yaitu masuknya unsur-unsur bahasa Thailand atau bahasa Melayu Pattani saat berinteraksi menggunakan bahasa Indonesia itu karena rasa daerah asal dari mahasiswa Thailand Universitas Jember itu yang masih melekat dan cukup kuat rasa kedaerahannya. Identifikasi campur kode karena faktor rasa kedaerahan ditentukan karena si penutur ingin menunjukkan kekhasan daerahnya sehingga menyebabkan penutur menggunakan bahasa daerah asalnya saat melakukan tuturan. Adapun campur kode faktor rasa kedaerahan tersebut dapat diperhatikan pada beberapa data berikut ini.

Konteks situasi :

Peristiwa tutur dilakukan oleh dua orang, orang pertama (O1) bernama Fatiha mahasiswa Thailand dan orang kedua (O2) bernama Maslahah mahasiswa Indonesia. Dua-duanya merupakan mahasiswa Jurusan Sejarah dan teman seangkatan yaitu Angkatan 2015. Percakapan terjadi di Gazebo Fakultas Ilmu Budaya Universitas Jember. Mereka sedang membicarakan apakah (O2) jadi pergi ke sekretariat anak Thailand. Percakapan dimulai saat (O1) memastikan (O2) benar datang ke sekretariat anak Thailand dengan menggunakan Bahasa Indonesia. Kemudian percakapan berlanjut hingga saat itu (O1) dalam tuturannya terjadi percampuran istilah bahasa lain yaitu bahasa Melayu Pattani. Pada saat itu (O2) menanggapi dengan menggunakan bahasa Indonesia. Hal itu seperti yang terdapat pada Data 12 di bawah ini.

Mahasiswa 1.1: Kamu ke sekret sama siapa kemarin?

Mahasiswa 2.1: Sama Nurul.

Mahasiswa 1.2: Kamu kost di mana?

Mahasiswa 2.2: Di jawa 6 sebelum cak Us. 
Mahasiswa 1.3: Maaf ya kemarin sayo gi doh [sayO gI dOh] ke Tulungagung. 'Maaf ya kemarin saya sudah pergi ke Tulungagung'

Dialog dan konteks situasi di atas memperlihatkan Fatiha mahasiswa Thailand menggunakan tuturan bahasa Indonesia yang di dalamnya tercampur tuturan bahasa Melayu Pattani. Penggunaan campur kode tersebut terjadi karena (O2) berasal dari Thailand tepatnya di daerah Thailand bagian selatan yaitu Pattani. Dilihat dari letak geografis, Thailand Selatan bersebelahan langsung dengan Malaysia, sehingga memiliki kemiripan dalam bahasa. Bahasa Melayu merupakan bahasa ibu bagi warga Thailand Selatan. Sama-sama bahasa Melayu tetapi dalam bahasa Melayu Pattani lebih dipersingkat dan hampir semua huruf vokal [a] di belakang kata akan berubah menjadi [o]. Kata gi [gI] dan doh [dOh] berasal dari kata pergi [pergI] dan sudah [sudOh] yang mengalami proses persingkatan bentuk, dan kata sayo [sayO] mengalami perubahan huruf vokal [a] di belakang kata yang berubah menjadi [o]. Dari data di atas dapat disimpulkan bahwa (O2) saat melakukan tuturan tercampur bahasa daerah asalnya karena masih melekat cukup kuat rasa daerah pada penutur itu sendiri. Faktor terjadinya campur kode pada tuturan $(\mathrm{O} 2)$ karena ingin menunjukkan kekhasan daerahnya.

\section{Faktor Keinginan untuk Menjelaskan dan Menafsirkan}

Suwito (1983:77) mengatakan faktor keinginan untuk menjelaskan dan menafsirkan tampak karena campur kode akan menandai sikap dan hubungannya terhadap orang lain serta sikap dan hubungan orang lain terhadap dirinya. Jadi, campur kode karena faktor keingginan untuk menjelaskan dan menafsirkan maksudnya yaitu masuknya unsur-unsur bahasa Thailand atau bahasa Melayu Pattani saat berinteraksi menggunakan bahasa Indonesia itu karena rasa keinginan penutur itu sendiri untuk menjelaskan apa yang sedang menjadi pokok pembicaraan. Adapun campur kode faktor keinginan untuk menjelaskan dan menafsirkan tersebut dapat diperhatikan pada beberapa data berikut ini.

Konteks situasi :

Peristiwa tutur dilakukan oleh dua orang, orang pertama (O1) bernama Ayu mahasiswa Indonesia dan orang kedua (O2) bernama Afnan mahasiswa Thailand. Dua-duanya merupakan mahasiswa Jurusan Sastra Indonesia dan teman seangkatan yaitu Angkatan 2016. Percakapan terjadi di depan ruang kelas Fakultas Ilmu Budaya waktu istirahat. Mereka sedang membicarakan rasa khas makanan di Thailand. Percakapan dimulai saat (O1) menawarkan makanan kepada (O2). Pada saat itu (O2) menanggapi pertanyaan dengan menggunakan bahasa Indonesia yang pada beberapa kata mengalami percampuran istilah bahasa lain yaitu bahasa Melayu Pattani. Kemudian (O1) menanggapi dengan sebuah pertanyaan untuk memastikan istilah bahasa tersebut, sesuai dengan arti yang dimengerti oleh (O1). (O2) menanggapi pertanyaan dari (O1) yang berisi pembenaran dari apa yang dimaksud (O1) hampir mirip dengan $(\mathrm{O} 2)$ maksud. Hal itu seperti yang terdapat pada data di bawah ini.

Mahasiswa 1.1: Kamu tau tape? Tape yang dari Bondowoso itu lo.

Mahasiswa 2.1 : Iya tau.

Mahasiswa 1.2 : Mau ini dong? Ambil dah makan. 
Campur Kode Penggunaan Bahasa Indonesia oleh Mahasiswa Thailand di Universitas Jember (Nurul Azizah, A.

Erna Rochiyati S., Edy Hariyadi)

Mahasiswa 2.2: Iya terimakasih.

Mahasiswa 1.3: Kalau di sini suku Jawa makanannya cenderung manis, kalau di Thailand?

Mahasiswa 2.3: Di sana itu masae [mase] gitu.

'Di sana itu rasa asam'

Mahasiswa 1.4: Masae itu kayak kecut gitu?

Mahasiswa 2.4: Iya kecut tapi ada manisnya.

Dialog dan konteks situasi di atas memperlihatkan bahwa $(\mathrm{O} 2)$ unsur bahasa lain saat menggunakan tuturan bahasa Indonesia. Bagian tuturan campur kode tersebut yaitu kata masae [mase] yang dalam bahasa Indonesia artinya 'asam' (Awabeen, Pembicaraan pribadi, 6 Maret 2019). Kata asam memiliki makna 'rasa seperti rasa cuka (KBBI V 0.2.1 Beta (21), 2016). Adanya beberapa perbedaan antara kebiasaan orang Indonesia dan Thailand, misalnya tentang rasa masakan. Oleh karena itu, dalam tuturan tersebut (O2) dengan sengaja mencampur bahasa Melayu Pattani ke dalam bahasa Indonesia. Adanya perbedaan arti rasa asam antara orang Indonesia dan Thailand. Campur kode dalam peristiwa tutur di atas terjadi pada tuturan $(\mathrm{O} 2)$ mempunyai tujuan untuk menjelaskan kepada (O1) terkait kata masae [mase] dalam konteks ini mempunyai maksud asam tetapi ada rasa manisnya. Dari data tersebut dapat disimpulkan bahwa (O2) melakukan campur kode tersebut karena ingin menjelaskan dan menafsirkan tuturannya agar (O1) memahami apa yang disampaikan.

\section{Faktor Tidak Adanya Konsep atau Istilah dalam Bahasa Indonesia}

Campur kode karena faktor rasa kedaerahan yaitu masuknya unsur-unsur bahasa Thai atau bahasa Melayu Pattani saat berinteraksi menggunakan bahasa Indonesia itu karena tidak adanya konsep atau istilah dalam bahasa indonesia. Identifikasi melakukan campur kode karena faktor tersebut, penutur tidak dapat menggambarkan pada istilah atau konsep dalam bahasa Indonesia dan ingin mempertegas pesan yang ingin disampaikan. Adapun campur kode faktor rasa kedaerahan tersebut dapat diperhatikan pada beberapa data berikut ini.

Konteks situasi :

Peristiwa tutur dilakukan oleh dua orang, orang pertama (O1) bernama Alifian mahasiswa Indonesia dan orang kedua (O2) bernama Hafizee mahasiswa Thailand. Dua-duanya merupakan mahasiswa Jurusan Hubungan Internasional dan teman seangkatan yaitu Angkatan 2016. Percakapan terjadi di depan ruang kelas Fakultas Ilmu Sosial dan Politik waktu istirahat. Mereka sedang membicarakan hasil nilai UAS. Percakapan dimulai saat (O1) menanyakan hasil nilai UAS kepada (O2). Pada saat itu (O2) menanggapi pertanyaan dengan menggunakan bahasa Indonesia yang pada beberapa kata mengalami percampuran istilah bahasa lain yaitu bahasa Melayu Pattani. Kemudian (O1) menanggapi dengan dengan bahasa Indonesia. Hal itu seperti yang terdapat pada data di bawah ini.

Mahasiswa 1.1: Gimana matkul Etnopolitik? Dapat nilai apa?

Mahasiswa 2.1: Siak roh[Siak rOh], dapat BC. Harus ngulang semester depan.

'Aduh, dapat BC. Harus ngulang semester depan'.

Mahasiswa 1.2: Terserah kalau itu mau ngulang juga tidak apa-apa. Mau ngulang kamu? 
Mahasiswa 2.2: Tak ngerti. Kalau ada temannya, nak ikut ngulang.

Dialog dan konteks situasi di atas memperlihatkan Kamae mahasiswa Thailand menggunakan tuturan bahasa Indonesia yang di dalamnya tercampur tuturan bahasa Melayu Pattani. Penggunaan campur kode tersebut terjadi karena (O2) ingin mempertegas pesan yang ingin disampaikan. Dalam tuturan tersebut ditemukan frasa Siak roh [Siak rOh] dalam bahasa Melayu Pattani merupakan salah satu umpatan yang cenderung sopan, dalam bahasa Indonesia memiliki arti 'aduh'. Dari data di atas dapat disimpulkan bahwa (O2) dengan sengaja mencampurkan bahasa Melayu Pattani ke dalam bahasa Indonesia, karena tidak ada padanannya istilah tersebut dalam bahasa Indonesia.

\section{Faktor Adanya Keterbatasan dalam Penguasaan Kata dalam Bahasa Indonesia}

Identifikasi faktor adanya keterbatasan mahasiswa Thailand dalam penguasaan bahasa Indonesia saat melakukan tuturan. Suwito (1983:77) Menyatakan bahwa, latar belakang terjadinya campur kode tersebut pada dasarnya dapat dikategorikan karena dua tipe, yaitu tipe yang berlatar belakang pada sikap (attitudinal type) dan tipe yang berlatar belakang kebahasaan (linguistic type). Faktor keterbatasan penguasaan dalam bahasa Indonesia, penutur mengalami kurangnya penguasaan kosa kata dalam bahasa Indonesia. Faktior itu muncul karena berlatar belakang kebahasaan (linguistic type) penutur. Adapun campur kode faktor adanya keterbatasan mahasiswa Thailand dalam penguasaan bahasa Indonesia tersebut dapat diperhatikan pada data berikut ini.

Konteks situasi :

Peristiwa tutur dilakukan oleh dua orang, orang pertama (O1) bernama Maslahah mahasiswa Indonesia dan orang kedua (O2) bernama Fatiha mahasiswa Thailand. Dua-duanya merupakan mahasiswa Jurusan Ilmu Sejarah, Fakultas Ilmu Budaya dan teman seangkatan yaitu Angkatan 2016. Percakapan terjadi di kantin Fakultas Ilmu Sosial dan Politik waktu istirahat. Mereka sedang membicarakan pengalaman (O2) yang saat liburan kuliah (O2) pulang ke Thailand. Percakapan dimulai saat (O1) menanyakan kehidupan sehari-hari di Thailand. Pada saat itu (O2) menanggapi pertanyaan dengan menggunakan bahasa Indonesia yang pada beberapa kata mengalami percampuran istilah bahasa lain yaitu bahasa Melayu Pattani. Kemudian (O1) menanggapi dengan dengan bahasa Indonesia. Hal itu seperti yang terdapat pada data di bawah ini.

Mahasiswa 1.1:Berubah model pakaian di Thailand, apa Fatihah gak mau berubah juga?

Mahasiswa 2.1: Berubah lah.

Mahasiswa 1.2: Oh sudah berubah. Apa bedanya pakaian di Thailand?

Mahasiswa 2.2: Pakaian anak-anak Thailand harus menurut kondisi, sing waed leom [sing waed leつm].

'Lingkungannya'

Mahasiswa 1.3: Kalau di sana gimana lingkungannya.

Mahasiswa 2.3: Harus pakai yang sopan. 
Dialog dan konteks situasi di atas memperlihatkan Fatiha mahasiswa Thailand menggunakan tuturan bahasa Indonesia yang di dalamnya tercampur tuturan bahasa Melayu Pattani. Dalam tuturan tersebut ditemukan frasa Sing waed leom [Sing waed le $\mathrm{Om}$ ] dalam bahasa Indonesia memiliki arti 'lingkungannya'. Mahasiswa 1 dalam peristiwa tutur tersebut dapat mengetahui arti kata Sing waed leom [Sing waed le $\mathrm{Om}$ ] karena mahasiswa 2 melakukan peragaan sehingga, Mahasiswa 1 dapat mengetahui apa yang dimaksud oleh mahasiswa 2. Saat melakukan tuturan, (O2) mengalami keterbatasan penguasaan kosakata dalam bahasa Indonesia, sehingga penutur memasukan bahasa Melayu Pattani dalam tuturan. Keterbatasan (O2) terwujud karena dia tidak mampu mengucapkan atau tidak mengetahui kosa kata dalam bahasa Indonesia. Hal itu terjadi karena (O2) mengalami keterbatasan dalam penguasaan kosa kata bahasa Indonesia.

\section{SIMPULAN}

Dari hasil penelitian dapat disimpulkan bahwa terjadinya campur kode dalam tuturan mahasiswa Thailand Universitas Jember saat menggunakan bahasa Indonesia. Campur kode yang terjadi masuknya bahasa Melayu Pattani dan bahasa Thailand ke dalam bahasa Indonesia. Campur kode yang lebih dominan dari bahasa Melayu Pattani karena bahasa Melayu Pattani menjadi bahasa ibu di Thailand Selatan, wilayah asal mahasiswa Thailand yang kuliah di Universitas Jember.

Bentuk campur kode dalam interaksi mahasiswa Thailand Universitas Jember dalam menggunakan bahasa Indonesia, terdiri atas: bentuk kata, bentuk frasa, dan bentuk klausa. Campur kode bentuk kata meliputi kata dasar, kata imbuhan, dan kata ulang. Campur kode bentuk kata dasar ditemukan dua bahasa, yaitu dalam bahasa Melayu Pattani pada kata masae [mase] 'asam' dan bahasa Thailand pada kata dai [dai]'boleh'. Campur kode bentuk kata imbuhan, pada kata pendidikae [pendidike] dalam bahasa Melayu Pattani sama dengan kata pendidikan dalam bahasa Indonesia, yaitu mengubah kata berakhiran -an dan -am menjadi vokal [e]. Campur kode bentuk kata ulang ditemukan dua bahasa yaitu bahasa Melayu Pattani pada kata macae-macae [mace- mace] 'macam-macam' dan bahasa Thailand pada kata chāâ-chāā [chaa-chaa]'pelan-pelan'. Bentuk frasa ditemukan campur kode dua bahasa yaitu bahasa Melayu Pattani dan bahasa Thailand. Contoh campur kode bahasa Melayu Pattani pada frasa lapae jae [lape jeh]'delapan jam'. Kata delapan dalam bahasa Indonesia menjadi lapae dalam bahasa Melayu Pattani, kata de pada awal kata hilang dan kata jam mengalami perubahan akhir kata karena untuk kata berakhiran -an dan -am dalam bahasa Melayu Pattani akan berubah vokal [e]. Contoh campur kode bahasa Thailand pada frasa Phoom long [Phoom lOng] 'lebih kurus'. Bentuk klausa contohnya klausa sayo gi doh [sayO $\mathrm{gI} \mathrm{dOh]} \mathrm{dalam} \mathrm{bahasa} \mathrm{Melayu} \mathrm{Pattani} \mathrm{'sebab} \mathrm{itu'} \mathrm{karena} \mathrm{mengalami} \mathrm{proses} \mathrm{penyingkatan.}$

Faktor-faktor yang melatarbelakangi terjadinya campur kode mahasiswa Thailand di Universitas Jember terdiri atas: 1) faktor rasa kedaerahan, 2) faktor keingginan untuk menjelaskan dan menafsirkan, 3) faktor tidak adanya konsep atau istilah dalam bahasa Indonesia, dan 4) faktor keterbatasan dalam penguasaan bahasa Indonesia.

Penelitian tentang campur kode penggunaan bahasa Indonesia oleh mahasiswa Thailand Universitas Jember sudah dilakukan dan ditemukan beberapa masalah yang perlu dikaji lebih lanjut. Oleh karena itu, diharapkan pada penelitian selanjutnya dapat meneliti dari 
sudut pandang lainnya seperti penggunaan bahasa, strategi pemilihan bahasa mahasiswa Thailand, atau interferensi bahasa oleh mahasiswa Thailand yang lebih kompleks dan menyeluruh dalam penggunaan bahasa. Selain itu juga dapat ditinjau dari aspek pragmatik dan sosiolingguistik lainnya, sehingga nantinya akan menghasilkan penelitian yang lebih bermanfaat dan dapat mengembangkan bidang ilmu lingguistik yang akan datang.

\section{DAFTAR PUSTAKA}

Alwasilah, A. C. 1993. Pengantar Sosiologi Bahasa. Bandung: Angkasa.

Chaer, A. 2012. Lingguistik Umum. Jakarta: Rineka Cipta.

Duerawee, A.M. 2016. "Keluasan Makna Kata-kata Bahasa Indonesia dan Kata Bahasa Melayu Pattani yang Digunakan oleh Mahasiswa Thailand di Universitas Muhammadiyah Surakarta". Tesis. Surakarta: Magister Pengkajian Bahasa, Sekolah Pascasarjana Universitas Muhammadiyah Surakarta.

Kamus Besar Bahasa Indonesia (KBBI). 2016. Luar Jaringan (offline). Jakarta: Pusat Bahasa Kementerian Pendidikan Nasional.

Mariagi, A. 2011. "Campur Kode Bahasa Inggris terhadap Bahasa Indonesia di Tabloid Bola: Tinjauan Sosiolinguistik”. Skripsi. Jember: Fakultas Sastra Universitas Jember.

Ramlan. 1983. Morfologi: Suatu Tinjauan Deskriptif. Yogyakarta: CV Karyono.

Ramlan. 1987. Sintaksis. Yogyakarta: CV Karyono.

Rosyid, A.A. 2015. "Campur Kode dalam Interaksi Santri Penutur Bahasa Madura di Lingkungan Sekolah MTS Unggulan Nurul Islam Antirogo Jember”. Skripsi. Jember: Fakultas Ilmu Budaya Universitas Jember.

Suwito. 1983. Pengantar Awal Sosiolinguistik: Teori dan Problema. Surakarta: Universitas Sebelas Maret University Prees.

www.kompasiana.com/2011 (diakses 12 Mei 2019).

www.surabaya.tribunnews.com/2015 (diakses 12 Mei 2019).

www.surabaya.tribunnews.com/2016 (diakses 12 Mei 2019).

Yuanita, S.A. 2012. "Campur Kode Bahasa Jawa terhadap Bahasa Indonesia dalam Interaksi Pembelajaran Guru di SMPN 1 Muncar, Kecamatan Muncar, Kabupaten Banyuwangi”. Skripsi. Jember: Fakultas Sastra UNEJ. 